\title{
A novel procedure to measure the antioxidant capacity of yerba maté extracts
} Procedimento padronizado para avaliar a capacidade antioxidante dos extratos de erva-mate Vanessa Graciela HARTWIG ${ }^{1 *}$, Luis Alberto BRUMOVSKY², Raquel María FRETES², Lucila SÁNCHEZ BOADO²

\begin{abstract}
Yerba maté extracts have in vitro antioxidant capacity attributed to the presence of polyphenolic compounds, mainly chlorogenic acids and dicaffeoylquinic acid derivatives. DPPH is one of the most used assays to measure the antioxidant capacity of pure compounds and plant extracts. It is difficult to compare the results between studies because this assay is applied in too many different conditions by the different research groups. Thus, in order to assess the antioxidant capacity of yerba maté extracts, the following procedure is proposed: $100 \mu \mathrm{L}$ of an aqueous dilution of the extracts is mixed in duplicate with $3.0 \mathrm{~mL}$ of a DPPH 'work solution in absolute methanol $\left(100 \mu \mathrm{M} . \mathrm{L}^{-1}\right)$, with an incubation time of 120 minutes in darkness at $37 \pm 1{ }^{\circ} \mathrm{C}$, and then absorbance is read at $517 \mathrm{~nm}$ against absolute methanol. The results should be expressed as ascorbic acid equivalents or Trolox equivalents in mass percentage ( $\mathrm{g} \% \mathrm{dm}$, dry matter) in order to facilitate comparisons. The AOC of the ethanolic extracts ranged between 12.8 and $23.1 \mathrm{~g}$ TE \% dm and from 9.1 to $16.4 \mathrm{~g} \mathrm{AAE} \% \mathrm{dm}$. The AOC determined by the DPPH assay proposed in the present study can be related to the total polyphenolic content determined by the Folin-Ciocalteu assay.
\end{abstract}

Keywords: DPPH; yerba maté; antioxidant capacity; Ilex paraguariensis.

\section{Resumo}

Extratos de erva-mate têm a sua capacidade antioxidante in vitro atribuída à presença de compostos polifenólicos, principalmente ácidos clorogênicos e derivados do ácido dicafeoilquínico. Embora DPPH seja um dos ensaios mais utilizados para avaliar a capacidade antioxidante dos compostos puros e extratos de plantas, o fato de que há uma padronização pobre na sua aplicação torna as comparações entre os diferentes extratos muito difíceis. Visando conseguir uma técnica padronizada para medir a capacidade antioxidante de extratos de erva-mate, propomos o seguinte procedimento: $100 \mu \mathrm{L}$ de uma diluição do extrato aquoso são misturados em duplicata, com 3,0 mL de uma solução de trabalho de DPPH em metanol absoluto (100 $\left.\mu \mathrm{M} . \mathrm{L}^{-1}\right)$, com um tempo de incubação de 120 minutos no escuro a $37 \pm 1{ }^{\circ} \mathrm{C}$ e, em seguida, a absorbância é lida a $517 \mathrm{~nm}$ contra o metanol absoluto. Os resultados devem ser expressos em equivalentes de ácido ascórbico ou de equivalentes de Trolox em percentagem de massa ( $\mathrm{g} \%$ de matéria seca), a fim de facilitar as comparações.

Palavras-chave: DPPH; erva-mate; capacidade antioxidante; Ilex paraguariensis.

\section{Introduction}

Mate or yerba maté (Ilex paraguariensis Saint Hil.) is a tree that grows in the central region of South America. A nutrient tea-like infusion commonly consumed in several South American countries is prepared from its leaf fraction. Due to its antioxidant capacity, the final product is used mainly in beverage industries, mostly energy drink industries, in Arabic countries, and more recently in the United States and Europe (HECK; SCHMALKO; GONZALEZ DE MEJIA, 2008)

Several studies on yerba maté have reported the presence of xanthines such as caffeine and theobromine, saponines, and several phenolic compounds, mainly chlorogenic acids and dicaffeoylquinic acid derivatives (FILIP et al., 2000; SCHINELLA et al., 2000; RAMIREZ-MARES; CHANDRA; GONZALEZ DE MEJIA, 2004; BORTOLUZZI et al., 2006;
GUGLIUCCI et al., 1996); Dudonne et al. (2009) reported $200 \mathrm{mg}$ gallic acid equivalents per $\mathrm{g}$ of powder extract and Bravo et al. (2007) reported $45 \mathrm{mg}$ caffeoyquinic acids per $\mathrm{g}$ of dry samples. It has also been reported that yerba maté extracts have an in vitro antioxidant capacity (AOC), which is due to the presence of polyphenolic compounds that have an antioxidant capacity equal to or higher than that of ascorbic acid and vitamin E (FILIP et al., 2000; SCHINELLA et al., 2000; RAMIREZ-MARES; CHANDRA; GONZALEZ DE MEJIA, 2004; GUGLIUCCI et al., 1996; CHANDRA; GONZALEZ DE MEJIA, 2004; GONZALEZ DE MEJIA et al., 2005). Dudonné et al. (2009) placed yerba maté aqueous extracts between the fifth plant extracts with higher antioxidant activity among 30 selected plants analyzed. Several methods have been proposed to measure

Received 3/8/2010

Accepted 12/7/2011 (004953)

${ }^{1}$ Consejo Nacional de Investigaciones Científicas y Técnicas, Departamento de Industrias, Facultad de Ciencias Exactas y Naturales, Universidad de Buenos Aires - UBA, Ciudad Autónoma de Buenos Aires, Pabellón Industrias, 1428, Buenos Aires, Argentina, e-mail: vanesshart@ yahoo.com.ar

${ }^{2}$ Facultad de Ciencias Exactas Químicas y Naturales, Universidad Nacional de Misiones - UNaM, Roque Perez, 1847, Piso 4, Departamento F, 3300, Posadas, Misiones, Argentina

${ }^{*}$ Corresponding author 
the antioxidant capacity of pure compounds and plant extracts, among them DPPH is one of the most used assays because it is a low-cost and simple technique and does not require sophisticated equipment; but its results depend highly on the conditions of the test used, e.g. the final concentration of the extracts, the initial concentration of the DPPH solution, the incubation time, and the solvent used for the DPPH solution (DUDONNE et al., 2009). The assay conditions vary a lot between the different research groups (Table 1); therefore the comparisons between the AOC of different extracts even from the same plant material are very difficult, and it is thus necessary to standarize the assay conditions to assess the AOC of yerba maté extracts. The aim of the present research was to propose a procedure to standardize the determination of the antioxidant capacity of yerba maté extracts. To achieve this, the Total Polyphenol Content (TPC) and the antioxidant capacity of the yerba maté extracts were determined; the no-interference of caffeine was verified; and the AOC of two pure substances wellrecognized for their action against the free radical DPPH and the repeatability and reproducibility of the method was evaluated.

\section{Material and methods}

\subsection{Reagents}

For the determination of the total polyphenol content, FolinCiocalteu's phenol reagent (Fluka, Argentina), chlorogenic acid (MP Biomedicals, Argentina) and anhydrous sodium carbonate (99\% purity, Anedra, Argentina), methanol (Merck, HPLC grade), and ethanol $96^{\circ}$, were used. For the determination of the antioxidant activity, DPPH (1,1-diphenyl-2-picrylhydrazyl, Sigma, Argentina), ascorbic acid (Sigma Ultra, Argentina), and Trolox (6-hydroxy-2.5.7.8-tetramethylchroman-2-carboxilic acid; Aldrich, Argentina) were employed. For the determination of the caffeine content, caffeine (Sigma Ultra, Argentina) and methanol (Merck, HPLC grade, Argentina) were used.

\subsection{Material}

Several yerba maté samples were purchased from a local industry in Apostoles, Misiones, Argentina. The leaf fraction of each sample was ground to pass a $4 \mathrm{~mm}$ screen and then sifted through a 40 -mesh sieve.

\subsection{Equipment}

Absorbance measurements were recorded with a UV/Vis spectrophotometer (Spectrum SP-2102, photometric accuracy $0.3 \% \mathrm{~T}$, spectrum bandwidth: $2 \mathrm{~nm}$ ). All samples were analyzed in $10 \mathrm{~mm}$ quartz cells at room temperature.

\subsection{Sample extraction}

Yerba maté extracts were prepared using $30 \mathrm{~g} \mathrm{dm}$ (dry matter) and an ethanol/water solution $(75 \% \mathrm{w} / \mathrm{w})$ with a ratio of $6 \mathrm{~g}$ liquid. $\mathrm{g}^{-1}$ of dry solid in a sealed Erlenmeyer flask and then kept in a thermostatic bath at $60 \pm 1{ }^{\circ} \mathrm{C}$ for 30 minutes with intermediate shaking. Next, the extracts were filtered (pore diameter $=1 \mathrm{~mm}$, and the recovered volume was recorded.
To evaluate the correlation between TPC and AOC against DPPH radical, yerba maté extracts were prepared in a sealed Erlenmeyer flask mixing $30 \mathrm{~g} \mathrm{dm}$ (dry matter) and an ethanol/ water solution (concentration (E) ranged between 25 and $75 \% \mathrm{w} / \mathrm{w}$ ) using different Liquid to Solid Ratios (LSR) (ranged between 5.2 and $10.8 \mathrm{~g}$ liquid. $\mathrm{g}^{-1}$ of dry solid) (Table 2). Next, the mixture was heated to $60 \pm 1{ }^{\circ} \mathrm{C}$ in a thermostatic bath for 30 minutes with intermediate shaking Subsequently, the extracts were filtered (pore diameter $=1 \mathrm{~mm}$ ).

To study the effect of incubation temperature on the free radical scavenging capacity of the extracts, the yerba maté

Table 1. Summary of some representative publications DPPH using antioxidant assay.

\begin{tabular}{|c|c|}
\hline $\begin{array}{l}\text { Initial concentration of } \\
\mathrm{DPPH}(\mu \mathrm{M})\end{array}$ & References \\
\hline 4 & Pineda Rivelli et al. (2007) \\
\hline 25 & $\begin{array}{l}\text { Göktürk Baydar, } \\
\text { Özkan and Yaşar (2007) }\end{array}$ \\
\hline 60 & $\begin{array}{l}\text { Brand-Williams, } \\
\text { Cuvelier and Berset (1995) }\end{array}$ \\
\hline 190 & Kevers et al. (2007) \\
\hline 500 & $\begin{array}{l}\text { Elzaawely, Xuan and Tawata (2007), } \\
\text { Chen et al. (2005) }\end{array}$ \\
\hline \multicolumn{2}{|l|}{ Reaction medium } \\
\hline Methanol & $\begin{array}{l}\text { Pineda Rivelli et al. (2007), } \\
\text { Kevers et al. (2007) }\end{array}$ \\
\hline Ethanol & Lo Scalzo (2000), Karioti et al. (2004) \\
\hline Toluene & Wettasinghe and Shahid (2000) \\
\hline Methanol buffered (pH 5.5) & Chen et al. (2005) \\
\hline \multicolumn{2}{|l|}{ Incubation time (minutes) } \\
\hline 5 & Kevers et al. (2007) \\
\hline 15 & Meda et al. (2005) \\
\hline 30 & Chen et al.(2005) \\
\hline 60 & Paixão et al. (2007) \\
\hline 120 & Pineda et al. (2007) \\
\hline 1440 & Thaipong et al. (2006) \\
\hline \multicolumn{2}{|l|}{ Wavelength $(\mathrm{nm})$} \\
\hline 515 & $\begin{array}{l}\text { Paixão et al. (2007), Brand-Williams, } \\
\text { Cuvelier and Berset (1995), } \\
\text { Thaipong et al. (2006), Saito et al. (2007) }\end{array}$ \\
\hline 517 & $\begin{array}{l}\text { Pineda et al. (2007), Chen et al. (2005), } \\
\text { Meda et al. (2005) }\end{array}$ \\
\hline
\end{tabular}

Table 2. Total polyphenol content and antioxidant capacity for extraction with several liquid to solid ratio and ethanol concentration.

\begin{tabular}{clrlc}
\hline RLS & E & \multicolumn{1}{c}{ CPT } & CAO-ET & CAO-EAA \\
\hline 6 & 25 & $11.0 \pm 0.00^{\mathrm{a}}$ & $18.6 \pm 0.07^{\mathrm{a}, \mathrm{d}}$ & $13.2 \pm 0.05^{\mathrm{a}, \mathrm{b}}$ \\
6 & 75 & $8.2 \pm 0.15^{\mathrm{d}}$ & $14.1 \pm 0.35^{\mathrm{e}}$ & $10 \pm 0.26^{\mathrm{e}}$ \\
10 & 25 & $13.4 \pm 0.40^{\mathrm{b}}$ & $21.8 \pm 1.49^{\mathrm{b}, \mathrm{c}}$ & $15.5 \pm 1.04^{\mathrm{c}, \mathrm{d}}$ \\
10 & 75 & $9.7 \pm 0.60^{\mathrm{c}}$ & $14.3 \pm 1.12^{\mathrm{e}}$ & $10.1 \pm 0.79^{\mathrm{e}}$ \\
10.8 & 50 & $12.8 \pm 0.20^{\mathrm{b}}$ & $23.1 \pm 0.46^{\mathrm{b}}$ & $16.4 \pm 0.35^{\mathrm{d}}$ \\
5.2 & 50 & $9.6 \pm 0.00^{\mathrm{c}}$ & $17.2 \pm 1.01^{\mathrm{d}}$ & $12.2 \pm 0.7^{\mathrm{a}}$ \\
8 & 85.25 & $7.0 \pm 0.15^{\mathrm{d}}$ & $12.8 \pm 0.01^{\mathrm{e}}$ & $9.1 \pm 0.01^{\mathrm{e}}$ \\
8 & 50 & $12.7 \pm 0.27^{\mathrm{b}}$ & $22.2 \pm 0.45^{\mathrm{b}}$ & $15.7 \pm 0.32^{\mathrm{d}}$ \\
\hline
\end{tabular}

Data are expressed as means \pm SE. Values bearing different letters are significantly different at $\mathrm{p} \leq 0.012$. LSR (liquid to solid ratio, g liquid/g dry solid); E (ethanol concentration, $\% \mathrm{w} / \mathrm{w})$; TPC: Total polyphenol content ( $\mathrm{g}$ CAE. $100 \mathrm{~g}^{-1} \mathrm{dm}$ ); AOC-TE: antioxidant activity (g TE. $100 \mathrm{~g} \mathrm{~g}^{-1} \mathrm{dm}$ ); AOC-AAE: antioxidant activity (g AAE. $100 \mathrm{~g}^{-1} \mathrm{dm}$ ). 
extracts were prepared using $0.200 \pm 0.001 \mathrm{~g}$ of each sample in an extraction tube and $5 \mathrm{~mL}$ of methanol $(70 \% \mathrm{v} / \mathrm{v})$ at $70{ }^{\circ} \mathrm{C}$. The extract was heated at $70{ }^{\circ} \mathrm{C}$ and mixed by vortex for 10 minutes. After cooling at room temperature, the extract was centrifuged for 10 minutes. The supernatant was decanted in a graduated tube. The extraction step was repeated twice. Both extracts were pooled and the final volume was adjusted to $10 \mathrm{~mL}$ with cold methanol (70\% v/v) (ISO/FDIS 14502-1) (INTERNATIONAL..., 2004). One milliliter of the extract was diluted with water to $30 \mathrm{~mL}$.

All the extractions were carried out in duplicate.

\subsection{Determination of total polyphenol content}

The Total Polyphenol Content (TPC) was determined using the Folin-Ciocalteu method (ISO 14502-1) (INTERNATIONAL..., 2004). The content was expressed as chlorogenic acid equivalents (CAE; $\mathrm{g} \% \mathrm{dm}$ ) using a chlorogenic acid (0-50 $\mu$ g.mL $\left.\mathrm{mL}^{-1}, \mathrm{R}^{2}=0.9995\right)$ standard curve. Each extract sample was diluted with water at 1:5 ratio and then 1:100.

One mililiter of the diluted sample extract was transferred in duplicate to separate tubes containing $5.0 \mathrm{~mL}$ of water-diluted Folin-Ciocalteu's reagent $(10 \% \mathrm{v} / \mathrm{v})$. Next, $4.0 \mathrm{~mL}$ of a sodium carbonate solution $(7.5 \% \mathrm{w} / \mathrm{v})$ was added. The tubes were then allowed to stand at room temperature for 60 minutes before absorbance was measured at $765 \mathrm{~nm}$ against distilled water. The concentration of polyphenols in the samples was derived from a standard curve of chlorogenic acid ranging from 0 to $50 \mu \mathrm{g} \cdot \mathrm{mL}^{-1}\left(\mathrm{R}^{2}=0.9995\right)$. The total polyphenol concentration in the original extracts (TPCo) was expressed as $\mu \mathrm{g}$ CAE. $\mathrm{mL}^{-1}$ of the original extract.

\subsection{Determination of the antioxidant activity by the DPPH assay}

The antioxidant activities of the extracts were determined as a measurement of radical scavenging using the $\mathrm{DPPH}$ radical. Briefly, $100 \mu \mathrm{L}$ of an aqueous dilution of the extracts was mixed in duplicate with $3.0 \mathrm{~mL}$ of a DPPH work solution in absolute methanol. The mixture was incubated for 120 minutes in the dark at room temperature, and the absorbance was then measured at $517 \mathrm{~nm}$ against absolute methanol. For the blank probe, the $100 \mu \mathrm{L}$ of diluted yerba maté extracts were replaced with $100 \mu \mathrm{L}$ of absolute methanol.

For the DPPH radical absorbance profile, $100 \mu \mathrm{L}$ of absolute methanol was mixed with $3.0 \mathrm{~mL}$ of a DPPH solution (DUDONNE et al., 2009) in absolute methanol, and the absorbance was measured immediately in a dark room; the range of the investigated DPPH concentrations was $10-200 \mu \mathrm{mol} . \mathrm{L}^{-1}$.

The results of the assay were expressed as ascorbic acid equivalents and Trolox equivalents (AAE; TE; g \% dm) and calculated as percentage of residual DPPH radical remaining at steady state, calculated with (Equation 1), where DPPHss was the concentration of radical DPPH at the steady state and DPPHo was the concentration at time zero (initial concentration), both expressed as $\mu \mathrm{mol} . \mathrm{L}^{-1}$. The AOC was calculated using (Equation 2), where $\mathrm{OV}=$ volume of the original extract $(\mathrm{mL})$,
$\mathrm{DV}=$ volume of the extract dilution $(\mathrm{mL}), \% \mathrm{H}=$ percentage of moisture in wet basis $(\mathrm{g})$, and $\mathrm{x}=$ amount of standard used in the reaction ( $\mu \mathrm{g}$ of standard) derived from the standard curves.

$$
\begin{aligned}
& \mathrm{R}=\frac{\mathrm{DPPHss} * 100}{\mathrm{DPPHo}} \\
& \mathrm{AOC}=\frac{0.1 * \mathrm{x} * \mathrm{DV} * 10 * \mathrm{OV}}{\mathrm{m}_{Y M} *(100-\% \mathrm{H})}
\end{aligned}
$$

The amount of total polyphenols in yerba maté extracts used in the reaction (PU) was calculated with (Equation 3), and the amount of DPPH radical used in the reaction (DU) was calculated with (Equation 4), both expressed in $\mu$ g, where CoPT was the concentration of total polyphenols in the original extract ( $\mu \mathrm{g}$ CAE. $\mathrm{mL}^{-1}$ of original extract), DV was the dilution volume of the extracts $(\mathrm{mL}), \mathrm{MW}$ was the molecular weight of the DPPH radical $\left(394.32 \mathrm{~g} \cdot \mathrm{mol}^{-1}\right)$, and DPPHo was the concentration of the DPPH radical in the working solution $\left(\mu \mathrm{mol} . \mathrm{L}^{-1}\right)$ (initial concentration), calculated from the absorbance profile of the radical.

$$
\begin{aligned}
\mathrm{PU} & =\frac{\mathrm{TPCo}}{10 * \mathrm{DV}} \\
\mathrm{DU} & =\frac{3 * \mathrm{MW}^{*} \mathrm{DPPHo}}{1000}
\end{aligned}
$$

\subsection{Effect of temperature on the free radical scavenging capacity}

To study the effect of incubation temperature on the free radical scavenging capacity of the yerba mate extracts, the reaction mixture was incubated for 120 minutes in the dark at four temperatures $\left(20,25,30\right.$, and $\left.40^{\circ} \mathrm{C}\right)$.

\subsection{Repeatability and reproducibility}

To evaluate the repeatability and reproducibility of the method, the extraction procedure was in accordance with the method described by the ISO 14502-1 (INTERNATIONAL..., 2004). The conditions to determine the repeatability were obtained using the same method in an identical test material in the same laboratory by the same operator using the same equipment within a short interval of time, and the conditions to determine the reproducibility were obtained using the same method in an identical test material in different laboratories with different operators using different equipment.

The values of repeatability, each of which is the average of five replicate test determinations, were calculated for test results. Three laboratories participated for each sample, and four test results per material were obtained; two samples were analyzed.

\subsection{Statistical analysis}

In order to evaluate the data, a linear regression, analysis of variance ( $\mathrm{pv} \leq 0.05)$ and Pearson`s Correlation techniques were used. Data are expressed as the means \pm standard error of two independent experiments carried out in duplicate.

\section{Results and discussion}

It is known that DPPH is one of the few stable and commercially available radicals capable of accepting an electron 
or a hydrogen radical to become a stable molecule. This radical has a maximum UV-vis absorption in the range between 515 and $519 \mathrm{~nm}$ (Figure 1), and it is used to evaluate the antioxidant capacity of specific compounds or extracts. The reaction is based on the color fading that takes place when its radical form is reduced by an antioxidant $(\mathrm{AH})$, or by a radical specie $(\mathrm{Re})$. The reaction progress is conveniently monitored by the decrease in the absorbance until the reaction reaches a plateu (BRAND-WILLIAMS; CUVELIER; BERSET, 1995). The basic reaction model is described in (Equation 5 and 6).(HUANG; OU; PRIOR, 2005)

$$
\mathrm{DPPH}^{-}+\mathrm{AH} \rightarrow \mathrm{DPPH}-\mathrm{H}+\mathrm{A}
$$

üüßüüüüt $\quad \cdot \quad \rightarrow$

Both ascorbic acid, which is a natural antioxidant, and Trolox, which is a synthetic water soluble compound equivalent to vitamin $\mathrm{E}$, are common antioxidants used as standards to compare the antioxidant potential. (CHAN et al., 2010; SHARMA; BHAT,2009).

According to Sharma and Bhat (2009), a good linear absorbance profile of DPPH radical diluted in methanol was observed in the range of DPPH concentrations between 10 and $200 \mu \mathrm{mol.L} \mathrm{L}^{-1}$ (Figure 2). It is desirable that the radical concentration during the assay varies in the range of accurancy of most spectrophotometers $(0.4<\mathrm{A}<0.9)$. Since above 0.9 , the measurement is probably not accurate, and below 0.4 , the differentiation between the sample and its reference may be difficult, $100 \mu \mathrm{mol} . \mathrm{L}^{-1}$ was chosen as the work solution concentration.

The DPPH radical concentration in the reaction mixture at any time was estimated from the absorbance profile of the DPPH radical, $y=0.0103 c-0.0013$, where $c=$ concentration of the DPPH radical $\left(\mu \mathrm{mol} . \mathrm{L}^{-1}\right)\left(\mathrm{R}^{2}=1\right)$ in the range between 10 and $100 \mu \mathrm{mol} . \mathrm{L}^{-1}$.

The length of the assay for the two standards and the yerba maté diluted extracts was estimated monitoring the absorbance decrease until the steady state was reached once the DPPH work solution was added to the sample solution. The dilutions of the yerba maté extracts tested were 1:75, 1:100, $1: 150,1: 200,1: 250,1: 300,1: 400$, and 1:500.

The reaction was developed in the dark at room temperature. The steady state was reached at 3,20, and 120 minutes for ascorbic acid, Trolox, and yerba maté extracts, respectively. The incubation time observed in yerba maté extracts was in agreement with the incubation time reported by Pineda Rivelli et al. (2007) for the AOC assessment in hydroalcoholic and aqueous yerba maté extracts by the DPPH assay.

The concentration of the standards ascorbic acid and Trolox (dissolved in methanol and diluted in water) were derived from the following standard curves ranging from 0 to $1.2 \mathrm{mmol} . \mathrm{L}^{-1}$, $y=-3.9808 x+99.996,\left(R^{2}=0.9984\right)$ and $y=-2.7675 x+99.054$ $\left(R^{2}=0.9991\right)$, respectively, where $y=\% R$ at the steady state and $\mathrm{x}=$ amount of standard used in the reaction ( $\mu \mathrm{g}$ of standard). According to Dae-Ok et al. (2002) the AOC of ascorbic acid is higher than that of Trolox.

The kinetic curves for the reaction between the DPPH radical and the standards or the polyphenols from the extracts for several mass ratios ( $\mu \mathrm{g}$ EAC. $\mu \mathrm{g}^{-1}$ of $\mathrm{DPPH}$ ) tested are presented in Figures 3, 4, and 5, respectively. An example of the significant reduction of the concentration of the radical DPPH in

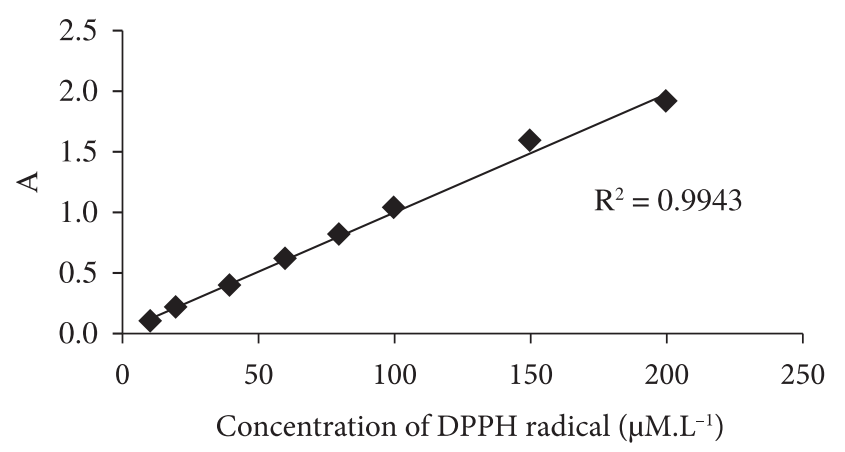

Figure 2. Absorbance of DPPH radical solutions prepared in methanol.

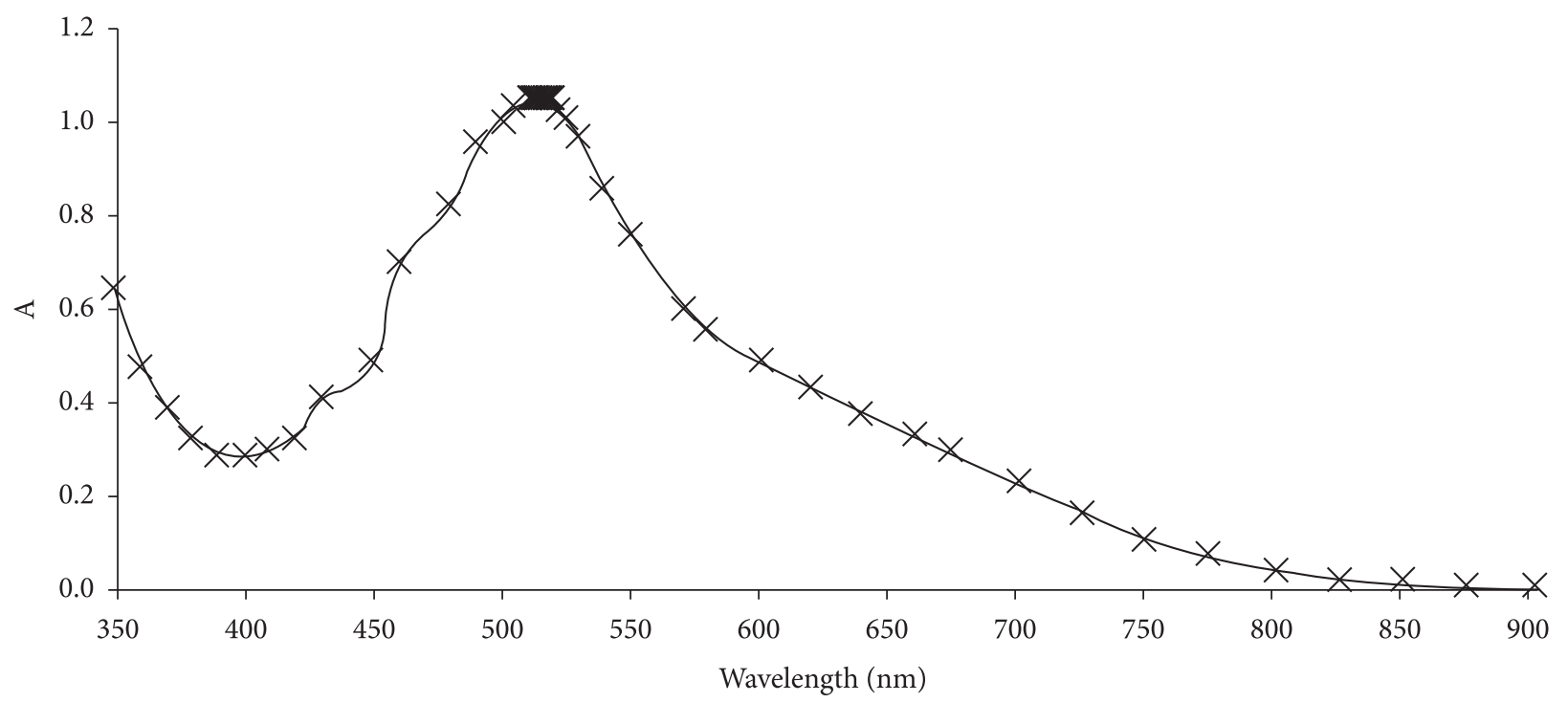

Figure 1. Absorbance of DPPH radical solution at tested wavelengths. 


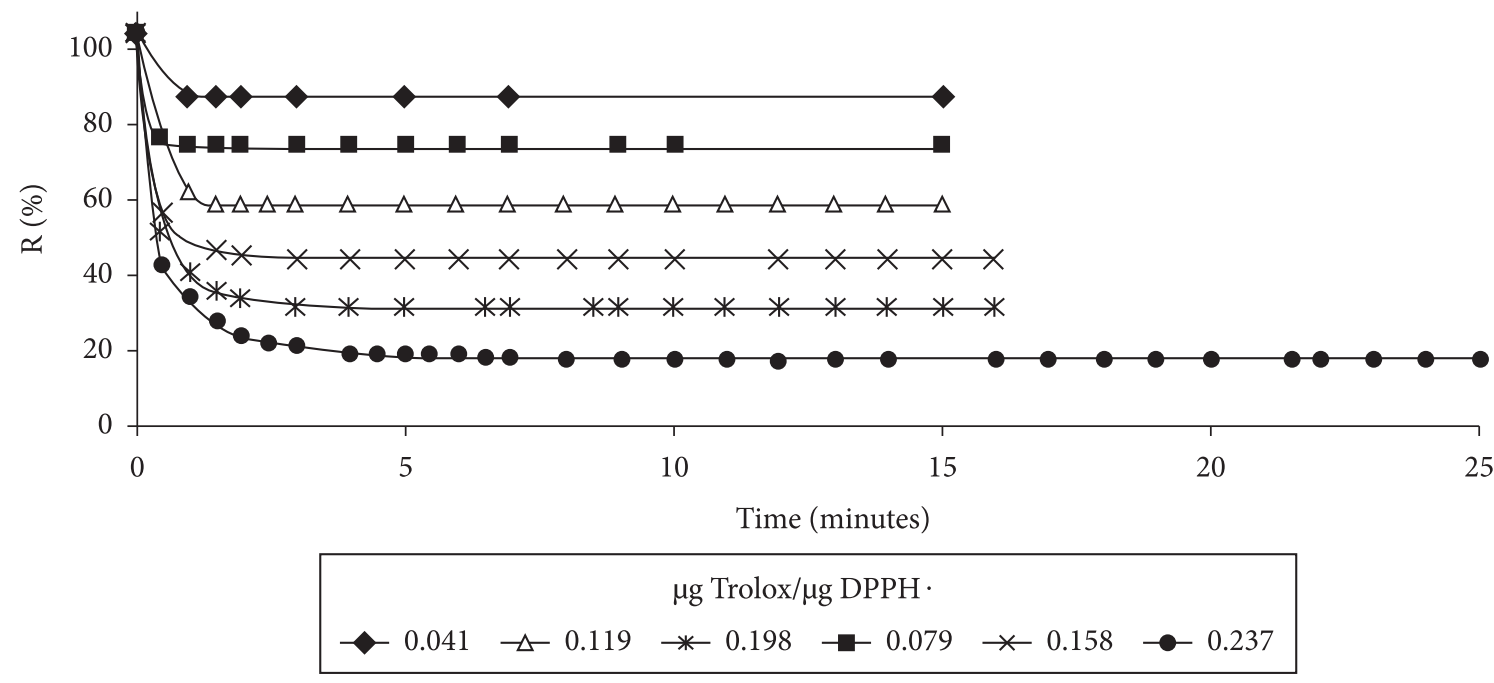

Figure 3. Time course of scavenging of the DPPH radical by Trolox.
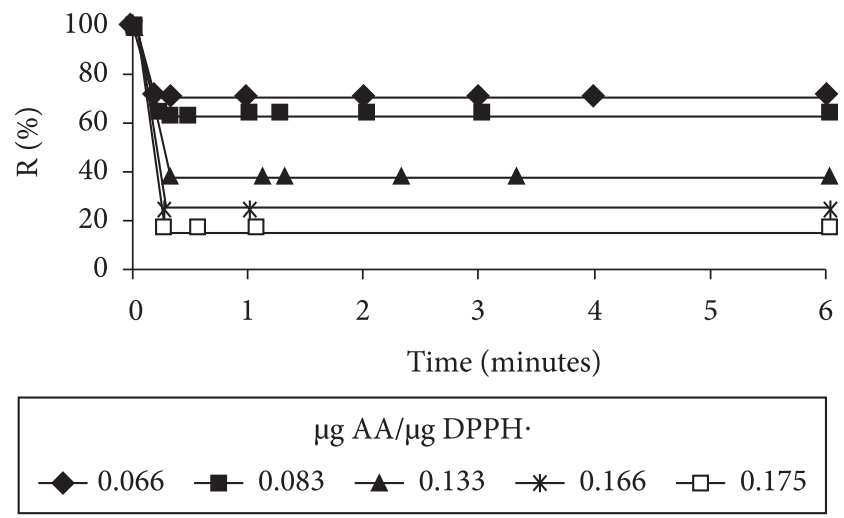

Figure 4. Time course of scavenging of the DPPH radical by Ascorbic Acid (AA).
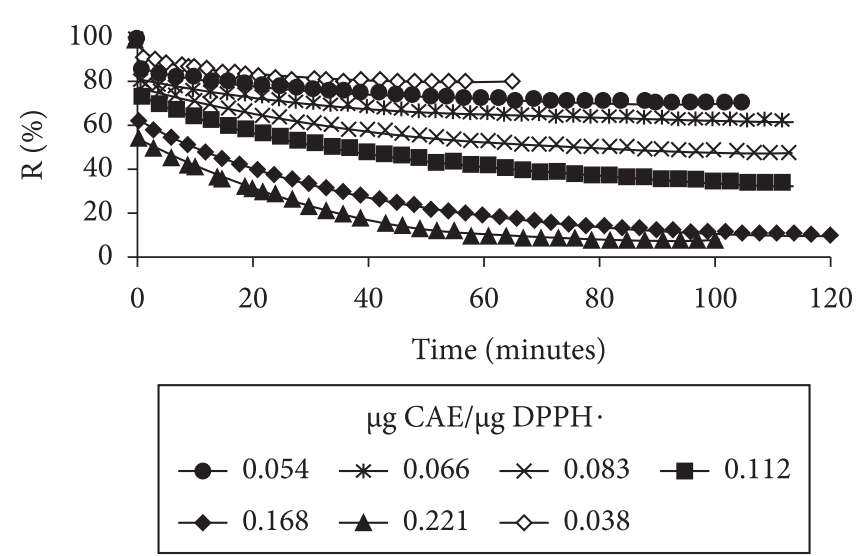

Figure 5. Time course of scavenging of the DPPH radical by yerba maté extracts.

the reaction mixture due to the free radical scavenging activity of the yerba maté extracts can be seen in Figure 5. It can also be observed that the most diluted extracts reached the steady state at shorter reaction times.
The TPC of the yerba maté extracts obtained was $8.25 \pm 0.15 \mathrm{~g} \mathrm{CAE} \% \mathrm{dm}$, the total polyphenol concentration CoPT was $20.772 \pm 1.019 \mathrm{mg} \mathrm{CAE} \cdot \mathrm{mL}^{-1}$, and the AOC was $10 \pm 0.26 \mathrm{~g} \mathrm{AAE} \% \mathrm{dm}$ and $14.1 \pm 0.35 \mathrm{~g} \mathrm{TE} \% \mathrm{dm}$.

A linear relationship between AOC and TPC $\left(\mathrm{R}^{2}=0.9874\right)$ can be observed in the range between 0 and $0.168 \mu \mathrm{g}$ CAE. $\mu \mathrm{g}^{-1}$ DPPH radical. Therefore, the ethanolic extracts of yerba maté should be diluted to ensure a polyphenol concentration of the diluted extract (TPCo) in the range between 90 and $105 \mu \mathrm{g}$ CAE. $\mathrm{mL}^{-1}$, so that the mass ratio between total polyphenol of the extract/radical DPPH is in the range between 0.075 and 0.088 . On the other hand, when extracts are obtained according to the procedure described in the standard ISO 14502-1 (INTERNATIONAL..., 2004), the TPCo should be in the range between 130 and $150 \mu \mathrm{g}$ CAE. $\mathrm{mL}^{-1}$.

As observed in a previous study (BENZIE; STRAIN, 1996), caffeine had no radical scavenging activity.

Numerous examples of the application of the FolinCiocalteu assay to assess the AOC of natural products may be found in the literature (HUANG; OU; PRIOR, 2005; TURKMEN; SARI, 2006). In most cases, total phenols determined by the Folin-Ciocalteu method are correlated with the antioxidant capacities confirming the value of the Folin-Ciocalteu test. In the present study, in order to evaluate the correlation between TPC and AOC against DPPH radical, eight different extracts from yerba mate using several solvent mixtures were assessed (Table 2); although the results showed that TPC varied considerably as a function of solvent nature, a high positive and significant correlation was found between the TPC and AOC using the DPPH method (Pearson's correlation coefficient, $\left.r^{2}: 0.96\right)$. This result indicates a relationship between phenolic compound concentration in yerba maté extracts and their free radical scavenging capacity. Therefore, the AOC determined by the DPPH assay proposed in the present study can be related to the total polyphenolic content determined by the Folin-Ciocalteu assay. 
Table 3. Repeatability from replicate measurements within a single laboratory.

\begin{tabular}{|c|c|c|c|c|}
\hline & \multicolumn{4}{|c|}{$\mathrm{AOC}$} \\
\hline & \multicolumn{2}{|c|}{$(\mathrm{g} \mathrm{AAE} \% \mathrm{dm})$} & \multicolumn{2}{|c|}{$(\mathrm{g}$ TE \% dm) } \\
\hline & Sample 1 & Sample 2 & Sample 1 & Sample 2 \\
\hline $\mathrm{N}^{\circ}$ of accepted ressults & 5 & 5 & 5 & 5 \\
\hline Average $\left(\mathrm{x}_{\mathrm{a}}\right)$ & 18.12 & 16.32 & 25.46 & 22.89 \\
\hline Standard deviation (DS) & 0.255 & 0.370 & 0.367 & 0.497 \\
\hline $\begin{array}{l}\text { Std. dev. of the results of } \\
\text { the test }\left(\mathrm{Sr}=\mathrm{DS}^{*} \mathrm{~m}^{-0.5}\right)\end{array}$ & 0.180 & 0.261 & 0.259 & 0.352 \\
\hline Repeatability $\left(r=2.77^{\star} \mathrm{S} r\right)$ & 0.499 & 0.724 & 0.719 & 0.974 \\
\hline $\begin{array}{l}\text { Repeatability in percentage } \\
\% \mathrm{r}=\left(100^{*} \mathrm{r} / \mathrm{x}_{\mathrm{a}}\right)\end{array}$ & 2.8 & 4.4 & 2.8 & 4.3 \\
\hline Repeatability average (\%) & \multicolumn{2}{|c|}{3.6} & \multicolumn{2}{|c|}{3.5} \\
\hline
\end{tabular}

Table 4. Test results from several laboratories.

\begin{tabular}{|c|c|c|c|c|}
\hline \multirow[b]{3}{*}{ Laboratory } & \multicolumn{4}{|c|}{$\mathrm{AOC}$} \\
\hline & \multicolumn{2}{|c|}{$(\mathrm{g}$ AAE $\% \mathrm{dm})$} & \multicolumn{2}{|c|}{$(\mathrm{g}$ TE $\% \mathrm{dm})$} \\
\hline & Average & Std. Dev & Average & Std. Dev \\
\hline 1 & 16.90 & 0.29 & 23.68 & 0.42 \\
\hline 2 & 16.75 & 0.25 & 23.48 & 0.36 \\
\hline 3 & 17.11 & 0.31 & 24.00 & 0.45 \\
\hline Average & 16.92 & 0.29 & 23.72 & 0.41 \\
\hline $\begin{array}{l}\text { Between Laboratory Std } \\
\text { Dev., Sn }\end{array}$ & \multicolumn{2}{|c|}{0.181} & \multicolumn{2}{|c|}{0.260} \\
\hline $\begin{array}{l}\text { Corrected between-Lab. Std. } \\
\text { Dev., SR }\end{array}$ & \multicolumn{2}{|c|}{0.231} & \multicolumn{2}{|c|}{0.332} \\
\hline $\begin{array}{l}\text { Reproducibility } \\
\text { (Between labs), } \mathrm{R}=2.77^{\star} \mathrm{SR}\end{array}$ & \multicolumn{2}{|c|}{0.639} & \multicolumn{2}{|c|}{0.919} \\
\hline $\begin{array}{l}\text { Reproducibility } \\
\text { (Between labs) (\%) }\end{array}$ & \multicolumn{2}{|c|}{3.8} & \multicolumn{2}{|c|}{3.9} \\
\hline
\end{tabular}

The higher the incubation temperature, the lower the concentration of the DPPH radical at the steady state (pv $\leq 0.0008$ ). This fact means higher AOC of the yerba maté extracts with the incubation temperature; therefore, we recommend $37 \pm 1{ }^{\circ} \mathrm{C}$ as the incubation temperature. This incubation temperature has also been used by other researchers for the assessment of AOC of several plant extracts and plasma (DUDONNE et al., 2009; BENZIE; STRAIN, 1996; PULIDO; BRAVO; SAURA-CALIXTO, 2000; SERAFINI et al., 2000).

The estimated precision from available data is presented in Tables 3 and 4 .

\section{Conclusions}

The results of the application of the DPPH radical assay to assess antioxidant capacity on either plant extracts or pure compounds highly depends on: the final concentration of the extracts, the initial concentration of the DPPH solution, the aliquots of the extracts and the DPPH solutions, the incubation time, and the solvent used for the DPPH solution.

In order to ensure the uniformity of the antioxidant capacity of yerba maté extracts by the DPPH free radical assay, the suggested procedure should be as follows: $100 \mu \mathrm{L}$ of an aqueous dilution of the extracts must be mixed in duplicate with $3.0 \mathrm{~mL}$ of a DPPH work solution in absolute methanol $\left(100 \mu \mathrm{mol} . \mathrm{L}^{-1}\right)$, with an incubation time of 120 minutes in darkness at $37 \pm 1^{\circ} \mathrm{C}$; and the absorbance must be read at $517 \mathrm{~nm}$ against absolute methanol.

For the blank probe, the $100 \mu \mathrm{L}$ of the diluted extracts must be replaced for $100 \mu \mathrm{L}$ of absolute methanol and the absorbance read at $517 \mathrm{~nm}$ must be $1.05 \pm 0.05$.

The results of the assay should be expressed as ascorbic acid equivalents or Trolox equivalents in mass percentage (dry matter) in order to facilitate comparisons.

The ethanolic extracts of yerba maté should be diluted to ensure a polyphenol concentration of the diluted extract in the range between 90 and $105 \mu \mathrm{g} \mathrm{CAE} \cdot \mathrm{mL}^{-1}$, so that the mass ratio between total polyphenol of the extract/radical DPPH is in the range between 0.075 and 0.088 . In contrast, when extracts are obtained according to the procedure described in the standard ISO 14502-1(INTERNATIONAL...,2004), the TPCo should be in the range between 130 and $150 \mu \mathrm{g} \mathrm{CAE} \cdot \mathrm{mL}^{-1}$.

Caffeine presented no radical scavenging activity against DPPH radical.

The AOC determined by the DPPH assay proposed in the present study can be related to the total polyphenolic content determined by the Folin-Ciocalteu assay.

The present proposed procedure has shown to be appropriate for the assessment of the in vitro antioxidant capacity of Ilex paraguariensis extracts and may contribute to they quality control. It can also be applied for the assessment of the antioxidant capacity of other plant extracts such as black and green tea or coffee.

\section{Acknowledgements}

The authors are grateful to the National Council of Scientific and Technical Research (CONICET) and National Institute of Yerba Mate (INYM) for the financial support and to DINCYT Foundation for the use of its laboratory equipment.

\section{References}

BENZIE I.; STRAIN J. The ferric reducing ability of plasma (FRAP) as a measure of "antioxidant power": the FRAP assay. Analytical Biochemistry, v. 239, p. 70-76, 1996.

BORTOLUZZI, A. et al. Cuantificacao de metilxantinas e compostos fenólicos en amostras comerciais de erva-meta (Illex paraguariensis Saint. Hilaire). In: SOUTH AMERICAN CONGRESS OF YERBA MATÉ, 4., 2006. Proceedings... Posadas, Misiones, 2006. p. 143-147.

BRAND-WILLIAMS, W.; CUVELIER, M. E.; BERSET, C. Use of a free radical method to evaluate antioxidant activity. Food Science and Technology, v. 28, p. 25-30, 1995.

BRAVO, L.; GOYA L.; LECUMBERRI, L. LC/MS characterization of phenolic constituents of mate (Ilex paraguariensis, St. Hil.) and its antioxidant activity compared to commonly consumed beverages. Food Research International, v. 40, p. 393-405, 2007. 
CHAN, E. W. C. et al. Antioxidant properties of tropical and temperate herbal teas. Journal of Food Composition and Analysis, v. 23, n. 2, p. 185-189, 2010.

CHANDRA, S.; GONZALEZ DE MEJIA, E. Polyphenolic compounds, antioxidant capacity, and quinone reductase activity of an aqueous extract of Ardisia compressa in comparison to mate (Ilex paraguariensis) and green (Camellia sinensis) teas. Journal of Agricultural and Food Chemistry, v. 52, p. 3583-3589, 2004.

CHEN, Y. C. et al. DPPH radical-scavenging compounds from DouChi, a soybean fermented food. Bioscience, Biotechnology and Biochemistry, v. 69, n. 5, p. 999-1006, 2005.

DAE-OK, K. et al. Vitamnin C equivalente antioxidant capacity (VCEAC) of phenolic phytichemicals. Journal of Agricultural and Food Chemistry, v. 50, p. 3713-3717, 2002.

DUDONNÉ, S. et al. Comparative study of antioxidant properties and total phenolic content of 30 plant extracts of industrial interest using DPPH, ABTS, FRAP, SOD and ORAC assays. Journal of Agricultural and Food Chemistry, v. 57, p. 1768-1774, 2009.

ELZAAWELY, A. A.; XUAN, T. D.; TAWATA, S. Essential oils, kava pyrones and phenolic compounds from leaves and rhizomes of Alpinia zerumbet (Pers.) B.L. Burtt. \& R.M. Sm. and their antioxidant activity. Food Chemistry, v. 103, p. 486-494, 2007.

FILIP, R. et al. Antioxidant activity of Ilex paraguariensis and related species. Nutrition Research, v. 20, n.10, p. 1437-1446, 2000.

GÖKTÜRK BAYDAR, N.; ÖZKAN G.; YAŞAR, S. Evaluation of the antiradical and antioxidant potential of grape extracts. Food Control, v. 18, p. 1131-1136, 2007.

GONZÁLEZ DE MEJIA, E. et al. Effect of yerba mate (Ilexparaguariensis) tea on topoisomerase inhibition and oral carcinoma cell proliferation. Journal of Agricultural and Food Chemistry, v. 53, p. 1966-1973, 2005.

GUGLIUCCI, A. Antioxidant effects of Ilex paraguariensis: induction of decreased oxidability of human LDL in vivo. Biochemical and Biophysical Research Communications, v. 224, p. 338-344, 1996.

HECK, C.; SCHMALKO, M. E.; GONZALEZ DE MEJIA, E. Effect of growing and drying conditions on the phenolic composition of mate teas (Ilex paraguariensis). Journal of Agricultural and Food Chemistry, v. 56, p. 8394-8403, 2008.

HUANG, D.; OU, B.; PRIOR, R. The chemistry behind antioxidant capacity assays. Journal of Agricultural and Food Chemistry, v. 53, p. 1841-1856, 2005.

INTERNATIONAL ORGANIZATION FOR STANDARDIZATION ISO 14502-1 Determination of total polyphenols in tea-Colorimetric method using Folin-Ciocalteau reagent. Part 1. International Organization for Standartzation, 2004.

KARIOTI, A. et al. Composition and antioxidant activity of the essential oils of Xylopia aethiopica (Dun) A. Rich. (Annonaceae) leaves, stem bark, root bark, and fresh and dried fruits, growing in Ghana. Journal of Agricultural and Food Chemistry, v. 52, p. 8094-8098, 2004.
KEVERS, C. et al. Evolution of antioxidant capacity during storage of selected fruits and vegetables. Journal of Agricultural and Food Chemistry, v. 55, p. 8596-8603, 2007.

LO SCALZO, R. Organic acids influence on DPPH scavenging by ascorbic acid. Food Chemistry, v. 107, p. 40-43, 2000.

MEDA, A. E. et al. Determination of the total phenolic, flavonoid and proline contents in Burkina Fasan honey, as well as their radical scavenging activity. Food Chemistry, v. 91, p. 571-577, 2005.

PAIXÃO, N. et al. Relationship between antioxidant capacity and total phenolic content of red, rosé and white wines. Food Chemistry, v. 105, p. 204-214, 2007.

PINEDA RIVELLI, D. et al. Simultaneous determination of chlorogenic acid, caffeic acid and caffeine in hydroalcoholic and aqueous extracts of Ilex paraguariensis by HPLC and correlation with antioxidant capacity of the extracts by DPPH• reduction. Brazilian Journal of Pharmaceutical Sciences, v. 43, n. 2, p. 215-222, 2007.

PULIDO, R.; BRAVO, L.; SAURA-CALIXTO, F. Antioxidant activity of dietary polyphenols as determined by a modified ferric reducing/ antioxidant power assay. Journal of Agricultural and Food Chemistry, v. 48, p. 3396-3402, 2000.

RAMIREZ-MARES, M.; CHANDRA, S.; GONZALEZ DE MEJIA, E. In vitro chemopreventive activity of Camellia sinensis, Ilex paraguariensis and Ardisia compressa tea extracts and selected polyphenols. Mutation Research, v. 554, p. 53-65, 2004.

SAITO, S. T. et al. Characterization of the constituents and antioxidant activity of Brazilian green tea (Camellia sinensis var. assamica IAC-259 cultivar) extracts. Journal of Agricultural and Food Chemistry, v. 55, p. 9409-9414, 2007.

SCHINELLA, G. R. et al. Antioxidant effects of an aqueous extract of Ilex paraguariensis. Biochemical and Biophysical Research Communications, v. 269, p. 357-360, 2000.

SERAFINI, M. et al. Inhibition of human LDL lipid peroxidation by phenol-rich beverages and their impact on plasma total antioxidant capacity in humans. Journal of Nutritional Biochemistry, v.11 p. 585-590, 2000.

SHARMA, O. P.; BHAT, T. K. DPPH antioxidant assay revisited. Food Chemistry, v. 113, p. 1202-1205, 2009.

THAIPONG, K. et al. Comparison of ABTS, DPPH, FRAP, and ORAC assays for estimating antioxidant capacity from guava fruits extracts. Journal of Food Composition and Analysis, v. 19, p. 669-675, 2006.

TURKMEN, N.; SARI, F. Effects of extraction solvents on concentration and antioxidant activity of black and black mate tea polyphenols determined by ferrous tartrate and Folin-Ciocalteu methods. Food Chemistry, v. 99, p. 835-841, 2006.

WETTASINGHE, M.; SHAHIDI, F. Evening primrose meal: a source of natural antioxidants and scavenger of hydrogen peroxide and oxygen-derived free radicals. Journal of Agricultural and Food Chemistry, v. 47, p. 1801-1812, 1999. 


\section{Nomenclature}

\begin{tabular}{|l|l|}
\hline A & absorbance \\
\hline AA & Ascorbic Acid \\
\hline AAE & Ascorbic Acid Equivalents \\
\hline AOC & antioxidant capacity \\
\hline CAE & Chlorogenic Acid Equivalents \\
\hline $\mathrm{dm}$ & dry matter \\
\hline DPPHo & concentration of radical DPPH at zero time (initial concentration) \\
\hline DPPHss & concentration of radical DPPH at steady-state \\
\hline DU & mass of DPPH radical used in the reaction \\
\hline DV & Dilution Volume \\
\hline g\% dm & g equivalents per 100 g of dry matter \\
\hline OV & recovered volume \\
\hline PU & mass of total polyphenols in yerba maté extracts used in the reaction \\
\hline TE & Trolox Equivalents \\
\hline TP & Total Polyphenols \\
\hline TPCo & Total Polyphenol Concentration in the original extract. \\
\hline TPC & polyphenol total content \\
\hline R & correlation coefficient \\
\hline $\mathrm{r}^{2}$ & Pearson's coefficient \\
\hline$\%$ R & percentage of residual DPPH radical remaining at steady state \\
\hline v/v & volume / volume \\
\hline w/w & weight/weight \\
\hline w/v & weight/volume \\
\hline
\end{tabular}

